\title{
TUGAS INDIVIDU PEMIKIRAN EKONOMI REVIEW JURNAL
}

" EVAMPING THE SUPPLY CHAIN OF FRUIT AND VEGETABLE IN EAST JAWA PROVINCE, INDONESIA"

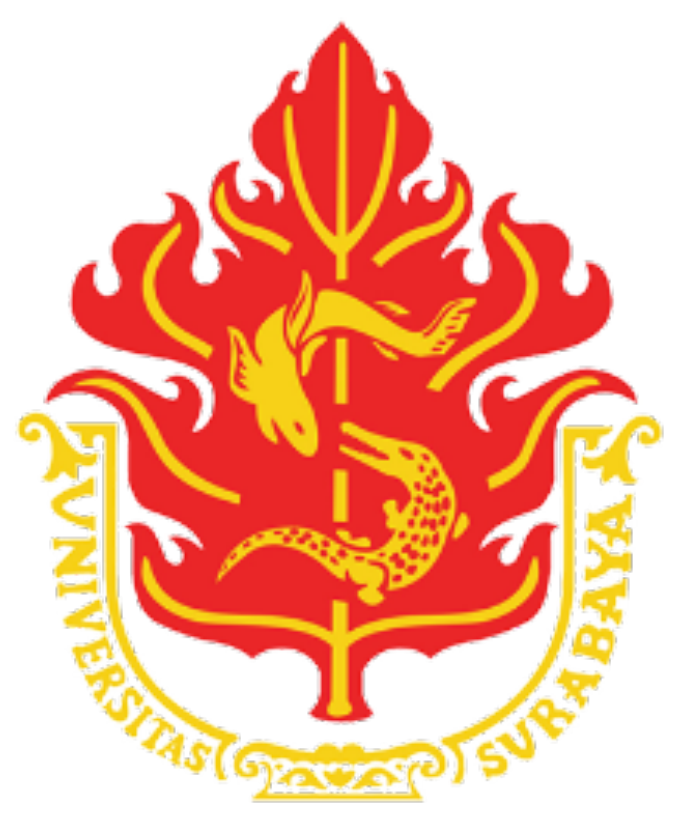

DI SUSUN OLEH :

Meliani Rosanty

(130218294)

KP A

FAKULTAS BISNIS DAN EKONOMIKA

UNIVERSITAS SURABAYA

2020 


\section{THE SUPPLY CHAIN OF FRUIT AND VEGETABLES IN EAST JAVA PROVINCE, INDONESIA}

Population growth and increasing public awareness of health increases demand for fruit and vegetables from year to year, both in quality and quantity. However, the increase in demand for fruit and vegetables has not been supported by supply or supply from production centers, thus increasing the increase in imports of fruits and vegetables to meet domestic demand. Several factors cause a reduction in the supply of products to the market each year between the price of the harvest of the product which doubles, but falls, so that fruit and vegetables are not sold and become spoilage. The problem, the government revealed that the problem occurred because of the bad trading system and limited innovation or technology. Where, the trading system is still controlled by economic actors (wholesalers) who can control prices. The limited information received by the farmers and the existence of a transportation and distribution network channel means that the products harvested cannot be sent to other areas quickly, so that most fruits and vegetables are easily damaged.

The refrigeration technology or storage needed to be able to withstand the life of fruit and vegetable commodities so that the supply to the market can be anointed properly and prices are not disturbed but still competitive.

Horticultural development has a vital role in encouraging economic growth and in increasing the income of fruit and vegetable producers in East Java by receiving added value. a sustainable process in a sustainable manner, creating adequate employment opportunities in rural areas, and increasing non-oil and gas exports. Horticultural development is expected to have great opportunities, because it rests on the foundation of comparative advantage in producing fruit and vegetables and creates market opportunities both at home and abroad. Likewise, the export market is also quite prospective considering the variety of products and specifications of tropical fruit that have not been produced by other countries.

The demand for fruits and vegetables tends to increase from year to year, both in quality and quantity. This condition is caused by population growth and increased community welfare due to the income and purchasing power of the community for horticultural products and awareness of the importance of quality nutrition and health. The demand for horticultural products in the domestic and global markets will continue to increase in line with world 
population growth in 2025. The total demand will increase in line with the increase in demand from the United States, European Union, Canada, Singapore, Hong Kong and Japan. However, the ability of farmers to produce fruit and vegetables has not been able to meet the large domestic and foreign markets due to limited land, use of semi-traditional cultivation technology, difficulty meeting quality standards, marketing to middlemen and wholesalers in the form of large parties without fruit and vegetable quality qualifications.

Supply chain relationships relationships are ongoing relationships regarding goods, money, and information. The main components in horizontal chain entry are suppliers, manufacturers, distributors, retailers and customers. Vertically in the form of maker, buyer, carrier, storage, and seller.

Supply chain management is the further integration of logistics management between the companies involved, with the aim of improving the flow of goods, increasing demand forecasts, increasing the efficiency of use of space, vehicles, reducing inventory levels, reducing costs, and improving other services required by end customers. In addition, related to product development, product quality assurance services, financial enhancement, after-sales, and information services. As the supply chain develops, there will be additional tasks assigned to the purchasing function, such as management, cost, time, technology, and supply continuity.

Input management can affect or fail of the output or the system as a whole. The value chain is a reflection of the strategy and implementation of the strategy as well as the economy that underlies the activities of a company which consists of a margin (difference in the total cost of value activities) and value activities (activity of technology) that are physically separated by a company implementation.

This research is a qualitative descriptive study that is an analysis of the condition of the fruit and vegetable value chain in Indonesia, especially in the economic sector in East Java Province. Where, the goal to be achieved in the form of making the facts easy to understand and possible to provide new hypotheses. In addition, a SWOT analysis is conducted for farmers to obtain a difference between the collective value of the value activities. The SWOT analysis includes:

- Strength (S)

1. a large show plot for fruits and vegetables

2. superior fashion and regional specialty fruits and vegetables

Weakness (W) 
1. A less aggressive marketing system

2. There is no guarantee of continuity of fruit and vegetable supplies

3 . High production cost per unit

- Opportunity (O)

1. Great alternative to the market

2. Many suppliers are available in the market

3. High foreign demand

- Threat (T)

1. Import good quality fruits and vegetables

2. Difficulty getting a fixed price

3. Transportation costs resulting from traffic jams

The strategies carried out include:

- SO strategy

1. Find new customers to increase sales volume

2. Market more aggressive fruits and vegetables

- WO strategy

1. Increase refrigerators and cold containers as storage areas

2. Improve delivery systems and retain repeat customers

- ST strategy

1. Improve the quality of fruits and vegetables so they can compete in the market

2. Entering the local market with competitive prices and quality

- WT strategy

1. Utilizing modern and environmentally friendly agricultural technology

2. Utilizing IT skills (online)

3. Eliminate regulations that hinder production and administration 
Horticultural commodities such as fruits and vegetables have a positive and large development prospect to diversify the menu for improving nutritional quality, to improve oil quality, and to maintain environmental beauty and sustainability. The development of vegetable crops is still largely financed by farmers' own funds, especially in production centers. There is no time to think about selling fruit and vegetables from village to village or market to market. Farmers in East Java now have to work out how to sell fruit and vegetables abroad. Where, Indonesia has been included in the list of 20 countries in the world that dominate fruit production in world trade. Indonesia has various types of native fruit that are of interest to the world market, such as pineapple, mangosteen, avocado and banana. The government must comply with regulations that hinder the production and marketing of horticulture, including the provision of logistical infrastructure to facilitate the transport of fruit and vegetables. There are sufficient refrigerators and cold storage needed by traders to supply fruit and vegetables throughout the year, so as not to focus on one season. 


\section{DAFTAR PUSTAKA}

Ahmad, Z. "Evamping the Supply Chain of Fruit and Vegetable in East Java Province, Indonesia" scholar google, 2019,

https://scholar.google.com/scholar?hl=id\&as sdt=0\%2C5\&q=ahmad+zafrullah+tay $\underline{\text { ibnapis\&btnG }=\& o q=a h m a d+z a f r u l l a}$ 